\title{
Ultrasonic estimates of fat thickness and longissimus dorsi muscle depth for predicting carcass composition of live Aragon lambs
}

\author{
R. Delfa ${ }^{\mathrm{a}, *}$, A. Teixeira ${ }^{\mathrm{b}}$, C. Gonzalez ${ }^{\mathrm{a}}, \mathrm{I}$. Blasco ${ }^{\mathrm{a}}$ \\ ${ }^{a}$ Unidad de Tecnología en Producción Animal, SIA-DGA, Apartado 727, 50080-Zaragoza, Spain \\ 'Instituto Politécnico de Bragança, Apartado 38, Bragança, Portugal
}

Accepted 6 June 1994

\begin{abstract}
Six ultrasonic fat and muscle depth measurements, taken on the left and the right side of the fourth lumbar vertebra and third sternebra of the breast bone, were related to carcass composition to determine the accuracy of these measurements for predicting carcass compositon of live Aragón lambs (Ternasco). Live weight alone accounted for 21, 19,26, 18 and 47\% of total variation of muscle, bone plus remainder, total fat, and subcutaneous and intermuscular fat, respectively. Addition of ultrasonic fat depth measurement on the right side of the lumbar region accounted for a further 18,31,33 and $36 \%$ of muscle, bone plus remainder, total carcass fat and subcutaneous fat, respectively. Addition of the same measurement taken on the left side accounted for a further $15 \%$ of intermuscular fat. Live weight alone accounted for only $4 \%$ of the total variation of kidney and pelvic fat, but the addition of ultrasonic fat depth measurement on breast bone accounted for a further $26 \%$ of the variation of this fat depot. The accuracy of prediction of carcass composition on live animals could be improved by the addition of ultrasonic fat measurements.
\end{abstract}

Keywords: Ultrasonics; Prediction of carcass composition; Aragon lambs

\section{Introduction}

Little information has been published about ultrasonics used in live ewes (Kempster et al., 1982a). Hiner (1958) suggested that ultrasonics are of little use in predicting fat thickness and longissimus dorsi muscle area of ewes. Nevertheless, Campbell et al. (1959) reported a significant correlation between longissimus dorsi muscle depth estimated by ultrasonics and measured on sheep carcass.

Moody et al. (1965), using 235 live lambs for a period of 3 years, showed that ultrasonics could predict with an acceptable accuracy the fat thickness and longissimus dorsi muscle area, whereas the correlation

\footnotetext{
* Corresponding author.
}

between longissimus dorsi muscle area assessed by ultrasonics in live animals and the same measurement obtained on the carcass was only 0.66 , and the correlation between subcutaneous fat thickness assessed by ultrasonics and the same measurement obtained on the carcass was 0.34 .

A study by Kempster et al. (1977) suggested that the scanogram measurements could be used in experimental work where it is necessary to select lambs for slaughter at constant fatness. Clements et al. (1981) showed that the accuracy of the scanogram was improved by the addition of a body weight (BW) term. Bass et al. (1982) suggested that some single probe ultrasonic machines can predict carcass composition of live sheep. Delfa et al. (1991) concluded that lumbar fat thickness measurements assessed by ultrasonics in 


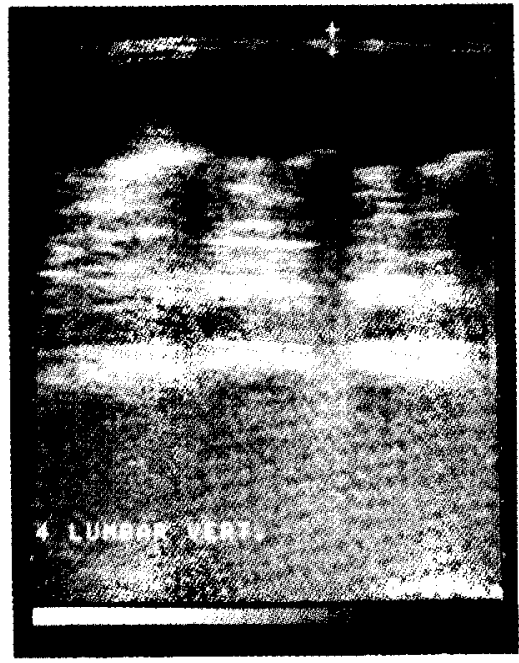

Fig. 1. Lumbar fat thickness assessed by ultrasonic machine.

live animals or measured on carcass were the best predictors of total carcass muscle and fat in Rasa Aragonesa ewes.

Currently the sheep industry in Aragón is concerned with producing leaner lambs with Ternasco characteristics. However, how can the industry identify superior

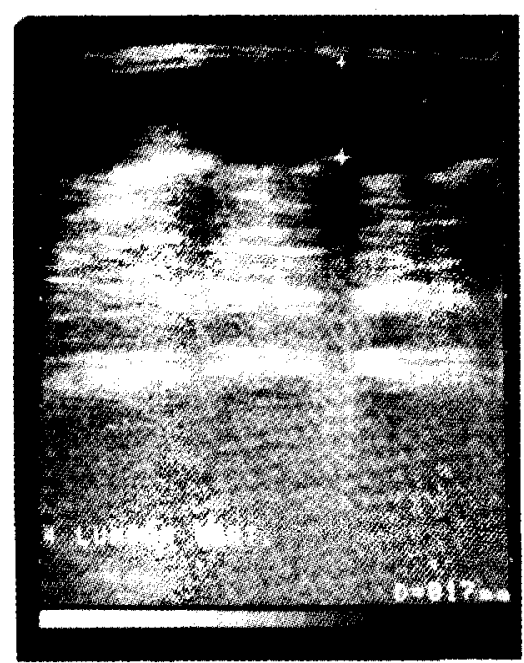

Fig. 2. Longissimus dorsi muscle depth assessed by ultrasonic machine. animals in order to produce more desirable carcasses according to the butchers' and consumers' preferences? The objective of the present study was to determine the accuracy of different ultrasonic fat and muscle depth measurements to predict carcass composition of live Aragon lambs of Ternasco type.

\section{Materials and methods}

A total of 29 Aragón male lambs of Rasa Aragonesa $(n=14)$ and Roya Bilbilitana $(n=15)$ breeds were taken from different flocks according to characteristics of the Consejo Regulador of Ternasco (BOA, 1989).

The designation of origin 'Ternasco de Aragón' comprises thuse carcasses from the extra and first categories weighing between 8.5 and $11.5 \mathrm{~kg}$, belonging to male lambs from the Rasa Aragonesa, Ojinegra de Teruel and Roya Bilbilitana breeds, without sex distinction between non-castrated males and females. Sheep farms must be located within the Autonomous Community of Aragón and lambs born and bred indoors.

Feeding must be maternal milk complemented with ad libitum white straw and concentrates authorized by the Regulating Council. The minimal period of natural lactation is 50 days. However, during weaning, ad libitum white straw and concentrate constitute the feeding. The concentrate must have a percentage of milk substitute fixed by the Regulating Council.

Slaughtering and carcass dressing must be performed in the Autonomous Community of Aragón. The live weight in the slaughterhouse must be between 18 and $24 \mathrm{~kg}$ and the age between 70 and 90 days.

Twenty-four hours before slaughter six ultrasonic fat and muscle depth measurements, taken on the left and the right side of the fourth lumbar vertebra (Figs. 1 and 2) and third sternebra of the breast bone (Fig. 3) (Delfa, 1992), were assessed using an ultrasonic machine (Toshiba Sonolayer scanner, Model Sal-32 B, with a $5.0 \mathrm{MHz}$ sounder). Lambs were fasted and then slaughtered in the experimental slaughterhouse of the Agricultural Research Service of the Autonomic Government of Aragón.

Carcasses were cooled at $6^{\circ} \mathrm{C}$ for $24 \mathrm{~h}$. Fat thickness was measured on the carcass with a caliper at the same anatomical point where it was assessed in the live animal using the ultrasonic machine. 


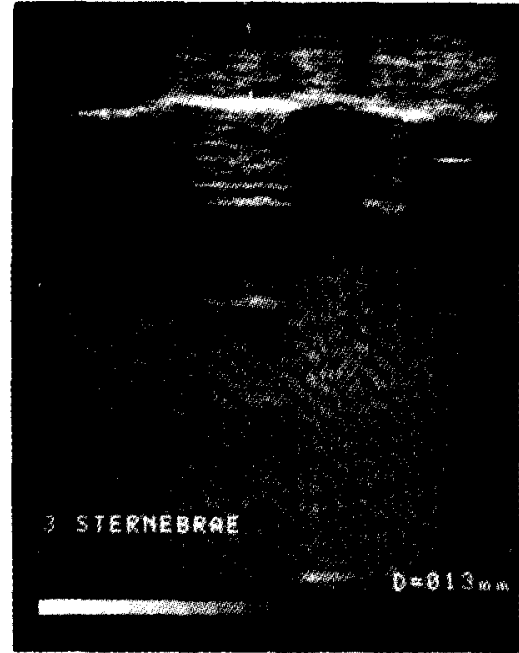

Fig. 3. All breast bone fat thickness assessed by ultrasonic machine.

Carcasses were halved carefully and the left side was dissected into muscle, bone plus remainder (major blood vessels, ligaments, tendons and thick connective tissue sheets associated with some muscles), subcutaneous and intermuscular fat, and kidney and pelvic fat (KKCF), according to the standard methods and procedures for lamb carcass evaluation suggested by Colomer-Rocher et al. (1988).

Regression analyses (Steel and Torrie, 1980) were developed for predicting muscle, bone plus remainder, total fat, subcutaneous and intermuscular fat, and $\mathrm{KKCF}$, using live weight and the six ultrasonic measurements. The statistics $R^{2}$ and residual standard deviation (RSD) were used to assess the accuracy of prediction of ultrasonic measurements (Kempster et al., 1982b).

\section{Results and discussion}

Means and standard deviations of BW, carcass composition and ultrasonic fat depth measurements are presented in Table 1 . The percentage of variation $\left(R^{2}\right)$ of carcass composition accounted for by $\mathrm{BW}$ alone, and the increase when paired with ultrasonic fat depth measurements, are given in Tables 2 and 3. BW alone accounted for $21 \%(P \leqslant 0.01), 19 \%(P \leqslant 0.01)$ and
$26 \%(P \leqslant 0.01)$ of total variation of muscle, bone plus remainder and total fat, respectively.

As shown by several authors (Shelton et al., 1977; Jones et al., 1982; Kempster et al., 1982a), BW was the most important measurement for prediction of the weight of lean carcass. However, our results show that $\mathrm{BW}$ does not offer much as a predictor of carcass composition, as many factors affect the rate and onset of fattening in meat animals.

Addition of the ultrasonic fat depth measurement, taken on the right side of the lumbar region, accounted for a further $18 \%(P \leqslant 0.05), 31 \%(P \leqslant 0.05)$ and $33 \%$ $(P \leqslant 0.0001)$ of the variation of muscle, bone plus remainder and total carcass fat, respectively.

Shelton et al. (1977) developed multiple regression equations using BW, rate of gain and ultrasonic measurements of fat thickness and longissimus area in live rams and found that $\mathrm{BW}$ was the dominant variable in the prediction of carcass retail yield, whereas ultrasonic measurements had no significant contribution.

As regards fat carcass depots, $\mathrm{BW}$ alone accounted for $18 \%(P \leqslant 0.01)$ and $47 \%(P \leqslant 0.0001)$ of total variation of subcutaneous and intermuscular fat respec-

Table 1

Means and standard deviations of carcass composition and ultrasonic depth measurements

\begin{tabular}{lrr}
\hline & Mean & Standard deviation \\
\hline Weights of carcass composition & & \\
Body weight (kg) & 21.37 & 0.86 \\
Cold carcass weight (kg) & 9.97 & 0.52 \\
Muscle (g) & 2741.61 & 164.86 \\
Bone + remainder (g) & 908.64 & 74.48 \\
Total fat (g) & 960.88 & 186.17 \\
Subcutaneous fat (g) & 349.88 & 102.98 \\
Intermuscular fat (g) & 497.18 & 51.98 \\
KKCF (g) & 158.45 & 48.22 \\
& & \\
Ultrasonic depth measurements $(\mathrm{mm})$ & \\
Lumbar C-left & 4.25 & 1.53 \\
Lumbar C-right & 4.11 & 1.37 \\
Lumbar B-left & 17.54 & 2.93 \\
Lumbar B-right & 17.04 & 2.44 \\
Subcutaneous breast bone & 3.07 & 0.80 \\
All breast bone & 18.48 & 2.32 \\
\hline
\end{tabular}

KKCF, kidney and pelvic fat. Lumbar $\mathrm{C}$, lumbar fat thickness measurement; lumbar $\mathrm{B}$, longissimus dorsi muscle depth in lumbar region; subcutaneous breast bone, subcutaneous breast bone fat thickness measurement; all breast bone, all breast bone fat thickness measurement. 
Table 2

Percentage variation $\left(R^{2}\right)$ of carcass composition accounted for by live weight and the increase when paired with various ultrasonic depth measurements

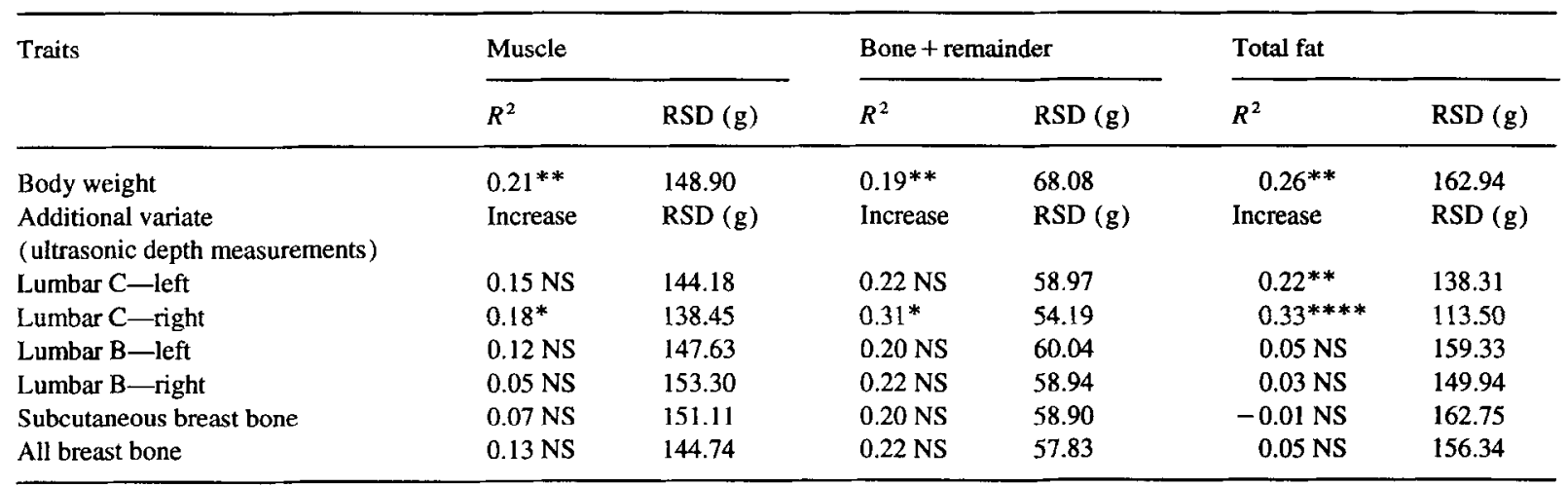

NS, not significant; *P<0.05; **P<0.01;***P<0.001; ****P<0.0001.

RSD, residual standard deviation.

tively; addition of the ultrasonic fat depth measurement on the right side, and addition of the same measurement taken on the left side, accounted for a further $36 \%$ $(P \leqslant 0.001)$ and $15 \%(P \leqslant 0.05)$ of the variation of these fat depots. BW alone accounted for $4 \%$ (not significant) of the total variation of KKCF, but addition of the ultrasonic fat depth measurement taken on the breast bone accounted for a further $26 \%(P \leqslant 0.01)$ of the variation of this fat depot.

In the study of Jones et al. (1982), locations of ultrasonic measurements were considered and it was found that fat depths on the 13 th rib gave the best prediction of carcass composition. In the present study, sites for measuring fat depth were the lumbar region and breast bone. Little information about this is available for lambs, but according to Hedrick (1983) the anatomical sites for fat and muscle measurements are the thoracic and lumbar areas of the body. This technique requires an experienced operator and the animal must be in a relaxed position.

The combination of two different measurements together with BW did not improve the prediction of carcass composition. For the experimental conditions in this study, the usefulness of ultrasonic fat depth measurements for estimating carcass composition appeared to be questionable. However, the data led to

Table 3

Percentage variation $\left(R^{2}\right)$ of carcass depots accounted for by live weight and the increase when paired with various ultrasonic depth measurements

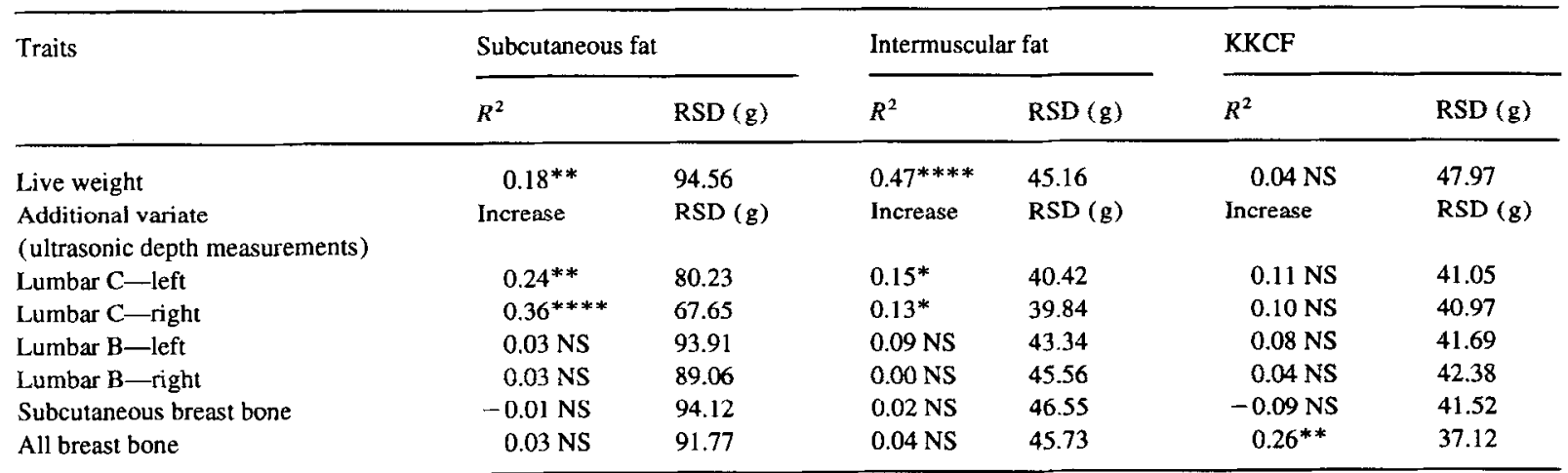

KKCF, kidney and pelvic fat.

NS, not significant; ${ }^{*} P<0.05 ; * * P<0.01 ; * * * P<0.001 ; * * * * P<0.0001$.

RSD, residual standard deviation. 
the conclusions that ultrasound can effectively measure fat thickness, and that these measurements can be combined with other live measurements to estimate carcass composition, mainly total fat and subcutaneous fat.

Nevertheless, as demonstrated by Thompson et al. (1977), Kempster (1981), Fortin and Shrestha ( 1986) and Edwards et al. (1989), the prediction of carcass composition of sheep using ultrasonic measurements is of limited application, and perhaps the use of another type of ultrasound machine and a different probe would determine lamb carcass composition more accurately.

\section{Acknowledgements}

This work has been supported by the CONAI of the Autonomic Government of Aragón (D.G.A.) as part of research nos. 689 and 904 .

\section{References}

Bass, J.J., Woods, E.G. and Paulsen, W.D., 1982. A comparison of three ultrasonics machines (Danscan, AIDD (NZ) and Body Composition Meter) and subjective fat and conformation scores for predicting chemical composition of live sheep. J. Agric. Sci., 99: 529-532.

BOA, 1989. Order dated 10 July 1989, from the Department of Agriculture, Animal Production and Forestry of the Autonomous Government of Aragón approving the Regulations for the Designation of Origin 'Ternasco de Aragón' and the corresponding Regulating Council. Bol. Of. Aragón, No. 78.

Campbell, D., Stonaker, H.H. and Esplin, A.L., 1959. The use of ultrasonics to estimate the size of the longissimus dorsi muscle in sheep. J. Anim. Sci., 24: 364-367.

Clements, B.W., Thompson, J.M., Harris, D.C. and Lane, J.G., 1981. Prediction of carcase fat depth in live lambs: a comparison of techniques. Aust. J. Exp. Agric. Anim. Husb., 21: 566-569.

Colomer-Rocher, F., Delfa, R. and Sierra-Alfranca I., 1988. Métodos normalizados para el estudio de los caracteres cuantitativos y cualitativos de las canales caprinas y ovinas. (Standardized method for the study of the quantitative and qualitative characters of sheep carcasses produced in the Mediterranean region, according to the production systems.) Cuad. INIA, 17: 19-41, in Spanish.

Delfa, R., 1992. Sheep carcass classification in the E.E.C. The Fifth Quarter. Serie Estudios Agrarios. Dirección General de Promo- ción Agraria, Departamento de Agricultura, Ganadería y Montes, Diputación General de Aragón, 177 pp., in Spanish.

Delfa, R., Teixeira, A., Blasco, I. and Colomer-Rocher, F., 1991. Ultrasonic estimates of fat thickness, $C$ measurement and longissimus dorsi depth in Rasa Aragonesa ewes with same body condition score. Options Mediterranéennes. Serie A: Seminaires Mediterraneens, 'Etat corporel des brebis et chevres', 13: 25-30.

Edwards, J.W., Cannell, R.C., Garret, R.P., Savell, J.W., Cross, H.R. and Longnecker, M.T., 1989. Using ultrasound, linear measurements and live fat thickness estimates to determine the carcass compositon on market lambs. J. Anim. Sci., 67: 3322-3330.

Fortin, A. and Shrestha, J.N.B., 1986. In vivo estimation of carcass meat by ultrasound in ram lambs slaughtered at an average live weight of $37 \mathrm{~kg}$. Anim. Prod., 43: 469-475.

Hedrick, H.B., 1983. Methods of estimating live animal and carcass composition. J. Anim. Sci., 57: 1316-1327.

Hiner, R.L., 1958. Sound waves measure fat and lean. Meats, December, p. 40. (Cited in Moody, W.G., Zobriski, S.E., Ross, C.V. and Naumann, H.D., 1965. Ultrasonics estimates of fat thickness and longissimus dorsi area in lambs. J. Anim. Sci., 24: 364-367.)

Jones, S.D.M., Walton, J.S., Wilton, J.W. and Szkotnicki, J.E., 1982. The use of urea dilution and ultrasonic backfat thickness to predict the carcass composition of live lambs and cattle. Can. J. Anim. Sci., 62: 371-379.

Kempster, A.J., 1981. The indirect evaluation of sheep carcass composition in breeding schemes, population studies and experiments. Livest. Prod. Sci., 8: 263-271.

Kempster, A.J., Cuthbertson, A., Jones, D.W. and Owen, M.G., 1977. A preliminary evaluation of the 'Scanogram' for predicting the carcass composition of live lambs. Anim. Prod., 24: 145-146, abstract.

Kempster, A.J., Arnall, D., Alliston, J.C. and Barker, J.D., 1982a. An evaluation of two ultrasonic machines (Scanogram and Danscanner) for predicting the body composition of live sheep. Anim. Prod., 34: 249-255

Kempster, A.J., Cuthbertson, A. and Harrington, G., 1982b. Carcase Evaluation in Livestock Breeding Production and Marketing. Granada Publishing, Granada, 306 pp.

Moody, W.G., Zobrisky, S.E., Ross, C.V. and Naumann, H.D., 1965. Ultrasonic estimates of fat thickness and longissimus dorsi area in lambs. J. Anim. Sci., 24: 364-367.

Shelton, M., Smith, G.C. and Orts, F., 1977. Predicting carcass cutability of Rambouillet rams using live animal traits. J. Anim. Sci., 44: 333-337.

Steel, R.G.D. and Torrie, J.H., 1980. Principles and Procedures of Statistics, 2nd edn. McGraw-Hill, New York, 633 pp.

Thompson, J.M., Pattie, W.A. and Butterfield, R.M., 1977. An evaluation of the 'Scanogram' as an ultrasonic aid in assessing carcase composition of live sheep. Aust. J. Exp. Agric. Anim. Husb., 17: 251-255.

\section{Resumé}

Delfa, R., Teixeira, A., Gonzalez, C. and Blasco, I., 1995. Ultrasonic estimates of fat thickness and longissimus dorsi depth for predicting carcass composition of live Aragon lambs. Small Rumin. Res., 16: 159-164. 
Un total de 6 mesures d'épaisseur du gras et du muscle, réalisées en utilisant des ultrasons sur la 4ème vertèbre lombaire et la 3ème sternèbre sternale, ont été rapportées à la composition de la carcasse, en ayant comme objetif d'étudier l'exactitude de ces mesures en tant qu'élément de prédiction de la composition de la carcasse d'agneaux vivants producteurs du 'Ternasco d'Aragón'.

Le poids vif à lui seul a expliqué $21,19,26,18$ et $47 \%$ de la variation totale du muscle, de l'os plus les déchets, du gras total et du gras souscutané et intermusculaire, respectivement.

L'addition des mesures d'épaisseur du gras (mesure C) réalisées par ultrasons sur le côté droit de la région lombaire, ont augmenté de 18, 31,33 et $36 \%$ la précision de l'estimation de la variation totale du muscle, de l'os plus déchets, du gras total et sous-coutané de la carcasse, respectivement. $L$ 'addition de la même mesure réalisée sur le côté gauche a augmenté de $15 \%$ la précision de l'estimation de la variation totale du gras intermusculaire.

Cependant, le poids vif n'a expliqué que $4 \%$ de la variation totale du gras pelvico-rénal, mais l'addition de la mesure d'épaisseur du gras sternal total, réalisée aux ultrasons, a augmenté de $26 \%$ la précision de l'estimation de la variation de ce dépôt adipeux.

La précision de la prédiction de la composition de la carcasse sur l'animal vivant pourrait augmenter par l'addition de mesures de l'épaisseur du gras réalisées aux ultrasons.

\section{Resumen}

Delfa, R., Teixeira, A., Gonzalez, C. and Blasco, I., 1995. Ultrasonic estimates of fat thickness and longissimus dorsi depth for predicting carcass composition of live Aragon lambs. Small Rumin. Res., 16: 159-164.

Un total de 6 medidas de espesor de grasa y músculo realizadas mediante la utilización de ultrasonidos sobre la $4^{\mathrm{a}}$ vertebra lumbar y la $3^{\mathrm{a}}$ estemebra del esternón fueron relacionadas con la composición de la canal, con el principal objetivo de estudiar la exactitud de estas medidas como predictoras de la composición de la canal de corderos vivos productores de 'Ternasco de Aragón'.

El peso vivo solo explicó el $21,19,26,18$ y $47 \%$ de la variación total del músculo, hueso más desechos, grasa total y grasa subcutanea e intermuscular respectivamente.

La adición de las medidas de espesor de grasa (medida $\mathrm{C}$ ) realizadas con ultrasonidos sobre el lado derecho de la región lumbar, incrementaron un $18,31,33$ y $36 \%$ la precisión de la estimación de la variación total del músculo, hueso más desechos, grasa total y subcutánea de la canal respectivamente. Y la adición de la misma medida realizada sobre el lado izquierdo incrementó un $15 \%$ la precisión en la estimación de la variación total de grasa intermuscular.

Sin embargo el peso vivo solo explicó el $4 \%$ de la variación total de grasa pelvico-renal, pero la adición de la medida de espesor de grasa total del esternón realizada con untrasonidos, incrementó un $26 \%$ la precisión de la estimación de la variación de este depósito adiposo.

La precisión de la predicción de la composición de la canal en el animal vivo podría ser incrementada con la adición de medidas del espesor de grasa realizadas con ultrasonidos. 